\title{
Medical Journals in Bosnia and Herzegovina from 1878 to 1945
}

\author{
Husref Tahirović ${ }^{1}$, Elnur Tahirović ${ }^{2}$
}

${ }^{1}$ Department of Medical Sciences of the Academy of Sciences and Arts of Bosnia and Herzegovina, Sarajevo, Bosnia and Herzegovina, ${ }^{2}$ Clinic for Cardiovascular Surgery, Clinical Center University of Sarajevo, Sarajevo Bosnia and Herzegovina

Correspondence:

husref.tahirovic@untz.ba

Tel./Fax.: + 38735303740

Received: 25 March 2018

Accepted: 30 May 2018

Key words: Medicine - Journal - Bosnia and Herzegovina - 1878-1945.
This paper presents the medical journals published in Bosnia and Herzegovina (BIH) in the period from 1878 to 1945 . The first medical journal in BIH may be deemed to be Jahrbuch des Bosnisch-Hercegowinischen Landesspittales in Sarajevo (The Yearbook of the National Hospital of Bosnia and Herzegovina in Sarajevo). In a special part of this journal, doctors from Austro-Hungary serving in Sarajevo wrote scholarly articles about their patients' various ailments. Up to 1945 seven more medical journals were published in BIH: Trezvenost - Organ Jugoslavenskog Saveza Trezvenosti (Temperance - the Journal of the Yugoslav Temperance Society), Zdravlje - Lekarske pouke o zdravlju i bolesti (Health, Medical lessons on Health and Disease), Glasnik Lekarske komore za Bosnu, Hercegovinu, Dalmaciju i Crnu Goru (The Journal of the Chamber of Physicians of Bosnia, Herzegovina, Dalmatia and Montenegro) Glasnik Lekarske komore Vrbaske banovine (Journal of the Chamber of Physicians of Vrbaska banovina, Glasnik Lekarske komore Drinske banovine (Journal of the Chamber of Physicians of Drinska banovina), Vjesnik Zavoda za suzbijanje endemijskog sifilisa u Bosni i Hercegovini (Journal of the Institute for Combatting Endemic Syphilis in Bosnia and Herzegovina) and Časopis za medicinu i biologiju (Journal for Medicine and Biology). Conclusion. Medical journals published in $\mathrm{BIH}$ in the period from 1878 to 1945 were published in times marked by specific political and social circumstances in $\mathrm{BIH}$, in the time when $\mathrm{BIH}$ was not independent, and was under the influence of the health culture of the ruling regimes. Most of the authors of the articles published in these journals were citizens of the occupying authorities, although the papers published were mainly the result of research undertaken in BIH.

\section{Introduction}

Journals have been the basic medium of professional and scholarly communication for more than three centuries. The first scientific journal in the world, Journal des sçavans, was published on 5 January 1665 (1) and, only fourteen years later, at the beginning of 1679 , the first general medical journal was published, entitled Les Nouvelles descouvertes sur toutes les parties de la médecine (2). Specialized medical journals were not published until the beginning of the $20^{\text {th }}$ century. Already from the beginning of publication of medical journals, they became the main link between medical science and practice. The launch of a medical journal and its continued publication are closely linked with the overall social circumstances and the degree of development of the medical profession and science in a specific academic environment.

At the very beginning of its rule, AustroHungary set about modernising Bosnia and Herzegovina (BIH) in the spheres of public and cultural life. Industrialization began, the 
schools were reformed, the health services were organized, the first scientific research began (3), and the question of the foundation of an archaeological society and museum was raised (4), which all together created the conditions for launching different scientific journals in BIH. From then, until the end of 1945, eight medical journals were appeared in BIH (Picture 1).

This paper presents medical journals published in BIH from 1878 to 1945.

\section{Medical Journals}

\section{Jarhbuch des bosnisch-hercegowinischen Landesspittales in Sarajevo (Yearbook of}

the National Hospital of Bosnia and Herzegovina in Sarajevo (Yearbook) (Picture 1a) was written in German. The first issue of the Yearbook was printed in 1894, which was also the year when the National Hospital was opened and began work in Sarajevo. A special part of the Yearbook was divided up according to various medical specializations, that is, according to the titles of the wards of the National Hospital. The chapter: "Bericht und Arbeiten der Internen Abtheilung" (Internal Medical Ward) was edited by Primarius Dr. Geza Kobler; the chapter "Bericht und Arbeiten Chirurgischen Abtheilung" (Surgical Ward) by Primarius Dr. Josef Preindlsberger; the chapter "Beri-

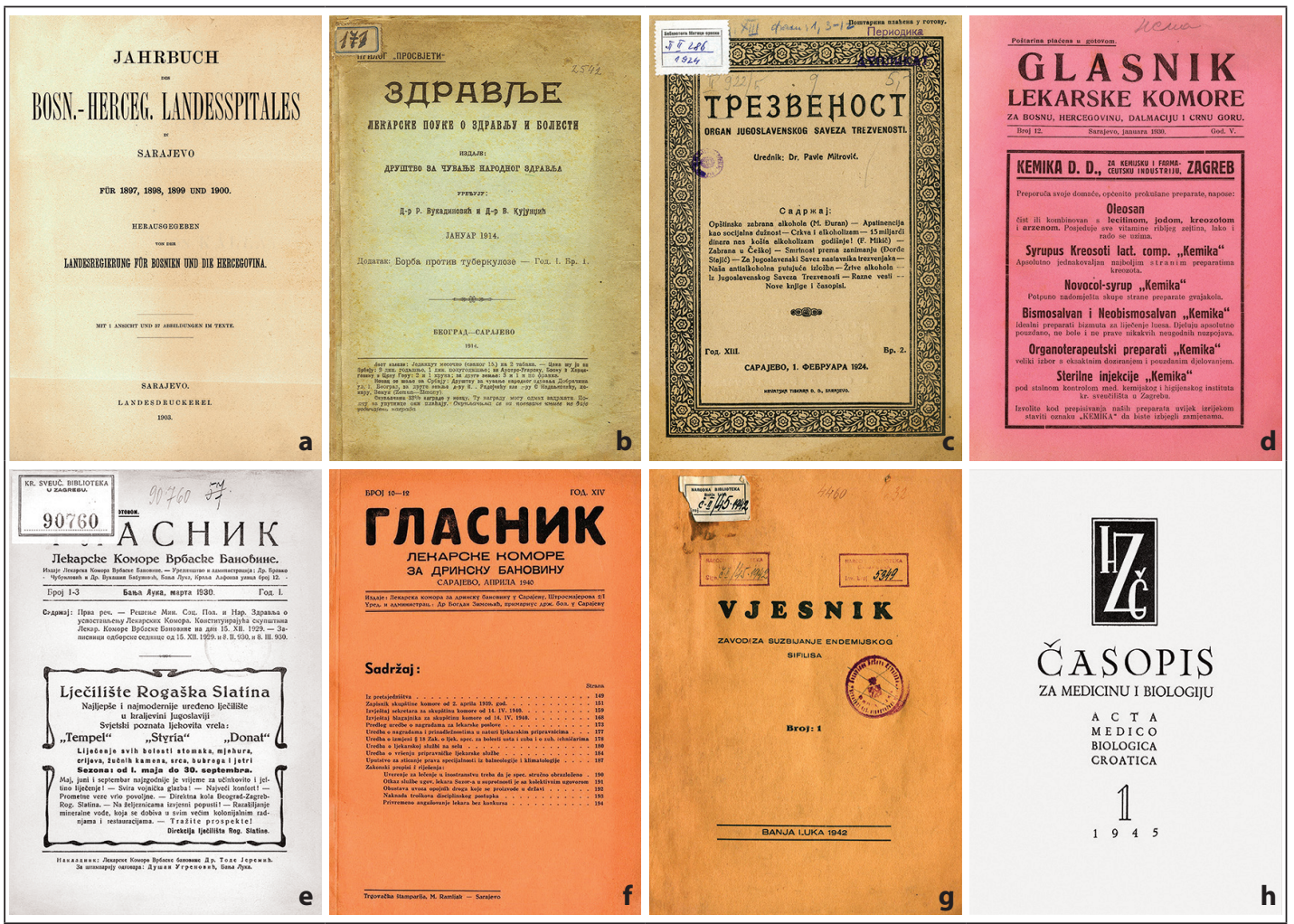

Picture 1. The title pages of medical journals in Bosnia and Herzegovina from 1878 to 1945: a) Godišnjak Zemaljske bolnice u Sarajevu (Yearbook of the National Hospital of Bosnia and Herzegovina in Sarajevo); b) Trezvenost - Organ Jugoslavenskog Saveza Trezvenosti (Temperance - the Journal of the Yugoslav Temperance Society); c) Zdravlje - Lekarske pouke o zdravlju i bolesti (Health, Medical lessons on Health and Disease); d) Glasnik lekarske komore za Bosnu, Hercegovinu, Dalmaciju i Crnu Goru (The Journal of the Chamber of Physicians of Bosnia, Herzegovina, Dalmatia and Montenegro); e) Glasnik Lekarske komore Vrbaske Banovine (Journal of the Chamber of Physicians of Vrbaska banovina; $f$ ) Glasnik Lekarske komore Drinske banovine (Journal of the Chamber of Physicians of Drinska banovina); g) Vjesnik Zavoda za suzbijanje endemijskog sifilisa u Bosni i Hercegovini (Journal of the Institute for Combatting Endemic Syphilis in Bosnia and Herzegovina); h) Časopisa za medicinu i biologiju - Acta medico-biologica Croatica (Journal for Medicine and Biology). 


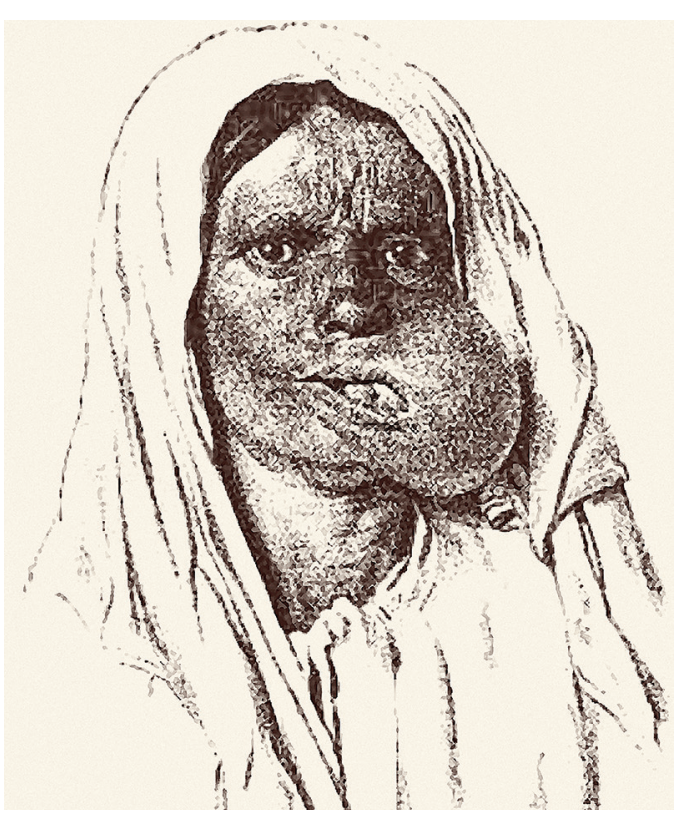

Picture 2. Pathological changes shown in a drawing in the Yearbook of the National Hospital in Sarajevo.

cht und Arbeiten der Abtheilung für Syphilis und Hautkranke" (Dermatology Ward) by Primarius D. Leopold Glück; the chapter: "Bericht und Arbeiten der Abtheilung für Geburtshilflich und Gynäkolgie" (Obstetrics and Gynaecology Ward) by Primarius and Docent Dr. Otto v. Weiss; the chapter "Bericht der Prosectur"(Dissection) by Prosector Dr. Roman Wodynski; and the chapter "Bericht der Apotheke" (Pharmacy) by Pharmacist Maks Teich (5). Physicians at the National Hospital in Sarajevo wrote a variety of medical articles in which they presented current hospital pathologies. According to Prof. Tatjana Praštalo, Doctor of Science in the field of librarianship, and for many years an employee of the National and University Library in Sarajevo, this special part of the Yearbook can be considered to be a forerunner of the first medical journal in BIH (6). The articles published were written according to the methodology of the time, and in that sense they did not lag far behind articles published in European medical journals of that time. It is interesting to note that the illustrations presenting various pathological states were in the form of drawings (Picture 2). The Yearbook was available to employees of the National Hospital in Sarajevo, but also to doctors working in smaller towns in the interior of $\mathrm{BIH}$, and the wider interested public.

Zdravlje - Lekarske pouke o zdravlju i bolesti (Health - Medical Lessons on Health and Disease) (Picture1b) was a journal that appeared in BIH in January 1914 (7). On the title page, the place of publication is given as "Belgrade-Sarajevo" which would indicate that it was a journal published jointly in Serbia and BIH. However, the publisher is listed as "The Society for Preservation of Public Health" from Belgrade. The editors of the journal were Dr. Radivoje Vukadinović and Dr. Vojislav Kujundžić, also from Belgrade. The year of publication is given as 1914. In the heading on the second page of the journal it states that this was the ninth year of publication, that the journal came out in print on the 1st January, and this was no. 1. That issue of the journal, apart from the place of issue, does not contain anything that to show that it was a medical journal from $\mathrm{BIH}$, which in that period had been annexed by the Austro-Hungarian Empire, and was a foreign country for Serbia. Why Sarajevo is listed together with Belgrade as the place of publication of this journal in that issue, and what the motives were for this, is still unknown and remains the subject of further speculation and research. The content of the journal comprises ten scholarly articles of an educational and informative nature, by authors from Serbia, mainly from Belgrade, written with the aim of educating the public about health.

Trezvenost - Organ Jugoslavenskog Save$z a$ Trezvenosti (The Journal of the Yugoslav Temperance Society) (Picture 2c) with the parallel title in French "Trezvenost" (Sobriete) Organe de la Ligue antialcoolique Yougslave" from Belgrade was transferred to Sarajevo by a decision of the Committee of the $\mathrm{Yu}$ - 
goslav Temperance Society of 3 November 1923 (8). It was published in Sarajevo from 1924 to 1926, after which it returned to Belgrade. Before it was published in Sarajevo, the Journal had already been published for 12 years, so the first year of its publication in Sarajevo was marked as Year XIII. At the time it was being published in Sarajevo, the Journal came out regularly once a month, sometimes in a double or triple edition. It was written alternately in Latin and Cyrillic script, and was distributed through its offices in Sarajevo, Belgrade, Zagreb and Ljubljana, to all corners of Yugoslavia. At that time the editor in chief was Dr. Pavle Mitrović, professor. The content of the journal comprised various scholarly articles of an educational and informative nature, in the fight against alcoholism, and articles relating to the work of the Yugoslav Temperance Society, articles about the fight against alcoholism in this country and abroad, reports from Congresses, and presentations of new national and foreign books on the harmfulness of alcohol and how to combat it, and quite often it also published advertisements by producers of non-alcoholic drinks.

Glasnik Lekarske komore za Bosnu, Hercegovinu, Dalmaciju i Crnu Goru (Journal of the Chamber of Physicians of Bosnia, Herzegovina, Dalmatia and Montenegro) (Picture 1d) was published in Sarajevo from 1925 to 1930 . The editor of the journal was the respected Sarajevo physician of that time, Dr. Vjekoslav Kušan, the secretary of the Chamber of Physicians. The first issue of the journal was published on 10th July 1925, and the last in January 1930. It was written alternately in the Cyrillic and Latin script. It was planned for the journal to come out four times a year, but it was issued occasionally, when necessary, and when sufficient material had been collected. A total of 19 issues were published. They were mainly articles relating to the work of the Chamber, but also articles of a professional and informative na- ture, of importance for the work of doctors $(9,10,11)$.

Glasnik Lekarske komore Vrbaske banovine (Journal of the Chamber of Physicians of Vrbaska banovina) (Picture 1e) was published in Banja Luka. The first issue came out in March 1930, as a triple edition (12). It was written alternately in Latin and Cyrillic script. Most probably this was also the only edition of this journal, because we have no knowledge of it being published later. The editors of the journal were Dr. Branko Čubrilović and Dr. Vukašin Babunović from Banja Luka. The content of the journal comprised articles on the foundation of the Chamber, some advertisements for various medical activities and products, and telegrams addressed to His Majesty King Aleksander I, King of Yugoslavia, and the Ministry of Social Policy and Public Health.

Glasnik Lekarske komore Drinske banovine (Journal of the Chamber of Physicians of Drinska banovina) (Picture 1f) came out occasionally from 1930 to 1941 in Sarajevo. The editor of the journal was the respected Sarajevo physician, Dr. Bogdan Zimonjić. The journal was written alternately in Cyrillic and Latin script. This was a continuation of the former Glasnik Lekarske komore za Bosnu i Hercegovinu, Dalmaciju i Crnu Goru (see above).

Vjesnik Zavoda za suzbijanje endemijskog sifilisa u Bosni i Hercegovini (Journal of the Institute for Combating Endemic Syphilis in Bosnia and Herzegovina) (Picture 1g) began to be published in 1942. The publisher was the institute for Combating Endemic Syphilis in Bosnia and Herzegovina (the Institute), based in Banja Luka, whose immediate work went on through the hygiene institutes of that time, public health centres and other health institutions in $\mathrm{BIH}$, and sometimes in improvised in-field clinics in remote Bosnian villages. I was unable to determine how this journal came to be launched. In the foreword of the first issue, 
written by Dr. Stanko Sielski, that information is not given, nor who the editor of the journal was. According to a statement made by Prim. Dr. Teodor Grüner (1913-2016), once a physician at the Institute, in March 2015, to the author of this article, the editor was Dr. Stanko Sielski. However, according to Jevtović (13), the editor in chief of the journal was Mery Atias-Günsberger, but I have been unable to establish that she was employed by the Institute. In the last issue of the journal in 1942, which came out as a double issue, in the article "Statistical Appendix II - a Brief Presentation of the First Year of Work to Combat Endemic Syphilis (14) written by Dr. E. R., it states that the Institute occasionally published a Vjesnik (Journal) in which doctors from the Institute presented their observations from the field, and discussed various epidemiological, clinical and serological questions regarding endemic syphilis, as well as questions about public health and national life, but he is not listed even in that text as the editor. The authors of the published articles were doctors at the Institute who had to sign their articles using their initials. In 1942 five volumes were issued, in that the fifth volume was marked as a double issue, 5 and 6 . At the end of each issue the contents are given, and in the double issue 5 and 6 there is an appendix on 4 pages of double sided paper, with the content of the Journal of the Institute for Combating Endemic Syphilis, 1942. A total of 35 articles were printed. The journal was printed on a hectograph, and each issue had separate page numbers. The covers of the journal were printed on stiff paper in different colours. I do not know if the journal came out later, since I was unable to find it in the archives of Dr. Stanko Sielski, or in libraries in BIH, Croatia and Serbia. Drago Njegovan in his article Jedna bibliografija periodik Nezavisne Države Hrvatske (19411945) (A Bibliography of Journals of the Independent State of Croatia, 1941-1945),
(15) under number 237, mentions the publication "Vestnik Zavoda za suzbijanje endemijskog sifilisa" (Journal of the Institute for Combating Endemic Syphilis), Banja Luka, II/1943. Biblioteka Zbora liječnika, Zagreb - 5652. When I traced this information I did not find that issue of the journal. However, it is strange that this bibliography did not mention any issues of the journal from 1942. After the first three issues of Vjestnik zavoda za suzbijanje endemijskog sifilisa, A.V. (A.V. correctly decoded: Dr. Ante Vuletić), at that time the editor in chief of Liječnički vjesnik (Medical Journal), and one of the organizers of the campaign to combat endemic syphilis, as well as to save his Jewish colleagues, published a presentation of those three issues of the journal, in which he states: "With the participation of 125 experts, 78 doctors and their observations it is completely understandable that such a major campaign does not have a purely practical purpose, that is, to wipe out once and for all endemic syphilis as an endemic disease, but also has the task of studying and to clarify many issues related to endemic syphilis. So in this way the campaign from a scientific point of view is making a valuable contribution to international venereology." In the text that follows he is critical of the linguistic roughness of the articles, but also recognises the head of the Institute, Dr. Stanko Sielski, who in those difficult circumstances still managed to launch a scholarly journal (16).

Časopis za medicinu i biologiju (Journal for Medicine and Biology) with the parallel title in Latin Acta medico-biologica Croatica (Picture 1h) appeared in $\mathrm{BIH}$ at the beginning of 1945. In the Impressum on the back page, under the title of the journal, it says: "founded by the medical faculties to mark the opening of the Medical Faculty in Sarajevo". The publisher of the journal was the Hrvatski izdavalački bibliografski zavod (The Croatian Publishing and Bibliographic Institute) of Zagreb. The chairman of the ed- 
itorial board was Prof. Dr. Ante Šercer, Dean of the Medical Faculty in Zagreb, and the editor of the journal was Dr. Josip Körbler, a professor at the Medical Faculty in Zagreb. The secretaries to the editor were Vjekoslav Duančić and Stanko Sielski, the Dean of the newly opened Medical Faculty in Sarajevo at that time. It was planned for the journal to come out four times a year. The first issue of the journal had eight articles written by authors from Zagreb. Each article had an Abstract in German, and a list of the literature used. A presentation of a book, Unutarnje bolesti (Botteri-Budak) (Internal Diseases) was also published. The journal also had these sections: Reviews, Presentations and News. It is interesting to note that this journal, after the Second World War, that is, after the break-up of the so-called Independent State of Croatia, was not issued either in Croatia or BIH, and the Medical Faculty in Sarajevo, for whose foundation in 1944 the journal was launched, was closed.

\section{Medical Articles in Non-Medical Journals}

Articles on medical subjects in the period from 1878 to 1945 were quite often published in journals issued by cultural and educational institutions, and cultural and educational societies. Some of those nonmedical journals had special sections in which articles were published in the field of medicine, or several medical articles were published in a single issue.

One of those journals was Glasnik Zemaljskog muzeja u Bosni i Hercegovini (The Herald of the National Museum of Bosnia and Herzegovina) (Herald), which began to the published in 1889 and was the first journal to be published in BIH with scholarly and scientific ambitions. As a multi-discipline and inter-discipline journal (17) it often published articles from the field of medical ethnography and anthropology. The journal was published in the Bosnian language, and it was written alternately in Cyrillic and Latin script. Up to the end of Austro-Hungarian rule in $\mathrm{BIH}$, the Herald) had published 35 articles whose contents related to public medicine and medical anthropology. The articles are interesting for the medical profession in $\mathrm{BIH}$ for many reasons and as such deserve to be the subject of new research, especially when we know that some of them were translated into German and published in the publication Wissenschaftliche Mitteilungen aus Bosnien und der Hercegowina $(18,19)$. Other non-medical journals occasionally published articles on medical topics. Examples of this are: Školski vijesnik, (School Journal) a journal published by the national government for Bosnia and Herzegovina published an article in 1905 "How Bosnian teachers can make a major contribution to the improvement of health" written by Dr. Justin Karlinski (20), the journal Prosvjeta, (Education) the Journal of the Prosvjeta society (Education), even had a separate section in issue 9 in 1919 entitled "Public Health" with 18 articles from the field of medicine, written on pages 149 to 180 (21), Novi Behar, (New Be-Har) the journal of the Muslim cultural society "Narodna uzdanica", (National Hope) in issue 12-13 of 1944 published four medical articles (22) and Napredak, (Progress) the Croatian national calendar, the journal of the Croatian cultural society of the same name, based in Sarajevo, in its second issue in 1908, published a medical article entitled "On Phthisis and Its Treatment (using juniper leaves)" (23).

Medical articles published in non-medical journals were mainly educational in nature, aimed at educating the general public regarding health matters. They were mainly written by doctors, but they were written in everyday language, in a simple style to make them accessible to a wide circle of readers. As far as I know, these articles have not yet been the subject of research, nor has any- 
thing been written about them, so that they are interesting for future research.

\section{Conclusion}

The medical journals mentioned above were issued or appeared in $\mathrm{BIH}$ at times when it was not independent, and was under the influence of the health culture of the occupying authorities and ruling regimes, at times which were marked by specific political and social circumstances. Most of the authors whose articles were published in these journals were citizens of the occupying authorities, although the articles published were mainly the result of research undertaken in $\mathrm{BIH}$. Of all these journals it may be said that they were published for a short time and that they mainly contained scholarly medical journals, which dealt with the health care and medical situation in $\mathrm{BIH}$ from various points of view. Medical articles published in non-medical journals in the period from 1878 to 1945 have not yet been the subject of research, nor has anything been written about them, so that they are interesting for future research.

Conflict of interest: The authors declare that they have no conflict of interest.

Authors' contributions: Conception and design: HT; Acquisition, analysis and interpretation of data: HT and ET; Drafting the article: HT and ET; Revising it critically for important intellectual content HT and, ET; Approved final version of the manuscript: HT and ET.

\section{References}

1. Norman J. Journal des sçavans: The First Scientific Journal Begins Publication (January 5 1665). History of Information.com [cited 2018 Jan 9]. Available from: http://www.historyofinformation.com/ expanded.php?id=2661.

2. Smith R. The trouble with medical journals. J R Soc Med. 2006;99:115-19.

3. Wikipedija. Bosnia and Herzegovina in AustroHungary [in Bosnian] [cited 2018 Jan 9]. Available from: https://hr.wikipedia.org/wiki/Bosna_i_ Hercegovina_u_Austro-Ugarskoj.
4. Kreševljaković H. Sarajevo at the Time of AustroHungarian Rule [in Bosnian]. Sarajevo: Arhiv Grada Sarajeva; 1969.

5. Yearbook of the National Hospital of Bosnia and Herzegovina in Sarajevo for 1894, 1895, 1896) [in German]. Vienna: Landesregierung für Bosnien und die Hercegovina; 1898.

6. Praštalo $\mathrm{T}$, Ćukac N. The Medical Journals in Bosnia and Herzegovina (1850-1990). Acta Informatica Medica. 1993;1:9-12.

7. Vukadinović R, Kujundžić V, editors. Health Medical Lessons on Health and Disease [in Serbian]. Beograd - Sarajevo: Društvo za čuvanje narodnog zdravlja; 1914.

8. Mitrović P, editor. Temperance 1924;13(1):1 [in Bosnian]. Sarajevo: Jugoslavenski Savez Trezvenost; 1924.

9. Kušan $\mathrm{Vj}$. A Good Book. Presentation of the Book by Dr. Bogoljub Konstantinović - Social Medicine [in Serbian]. Glasnik Lekarske komore za Bosnu, Hercegovinu, Dalmaciju i Crnu Goru. 1928;4(10):167-70.

10. Kornfeld M. Doctors and the New Criminal Code and Criminal Procedure 1 [in Serbian]. Glasnik Lekarske komore za Bosnu, Hercegovinu, Dalmaciju i Crnu Goru. 1929;5(6):65-80.

11. Kornfeld M. Doctors and the New Criminal Code and Criminal Procedure 2 [in Serbian]. Glasnik Lekarske komore za Bosnu, Hercegovinu, Dalmaciju i Crnu Goru. 1929;5(7):81-96.

12. Čubrilović B, Babunović V, editors. Journal of the Chamber of Physicians of Vrbaska banovina 1930:1(1-3) [in Serbian]. Banjaluka: Lekarska komora Vrbaske banovine; 1930.

13. Jevtović S. The Work of Jewish Physicians in Bosnia and Herzegovina, 1941-1942 [in Croatian]. Novi Omanut. 2001;46:9-10.

14. Dr. E. R. Statistical Appendix II - A Brief Presentation of the First Year of Work Combating Endemic Syphilis [in Bosnian]. Vijesnik Zavoda za suzbijanje endemijskog sifilisa. 1942;1(5/6):65-9.

15. Njegovan D. A bibliography of the journals of the Independent State of Croatia - 1941-1945 [in Serbian] [cited 2018 Feb 9]. Available from: http:// docplayer.net/25767786-Jedna-bibliografija-periodike-nezavisne-dryave-hrvatske.html.

16. A.V. Journal of the Institute for Combating Endemic Syphilis [in Croatian]. Liječ vjesn. 1942;64(10):393-4.

17. Editorial Board of the Journal. To the readers of "Glasnik" [in Bosnian]. Glasnik Zemaljskog muzeja u Bosni i Hercegovini. 1889;1(1):1-5.

18. Glück L. Sketches of Folk Medicine and Medical Superstition in Bosnia and Herzegovina [in Ger- 
man]. Wissenschaftliche Mitteilungen aus Bosnien und der Herzegowina, 1894:2:392-454.

19. Čorović V. The Scientific Work of the National Museum [in Bosnian]. Glasnik Zemaljskog muzeja u Bosni i Hercegovini. 1914;26:3-34.

20. Karlinski J. Teachers and Public Health [in Bosnian]. Školski vijesnik. 1905;12;281-3.

21. Slijepčević P, editor. Education, the Journal of the Education Society 1919;9(9) [in Serbian]. Sara- jevo: Srpsko kulturno - prosvjetno društvo Prosvjeta; 1919.

22. Nametak A, edtor. New Be-Har - Magazine for Education and Amusement 1944;16(12/13) [in Bosnian]. Sarajevo: Hrvatsko muslimansko kulturno društvo "Narodna uzdanica"; 1944.

23. Marić F. Overview of the Croatian Calendars of the Society Progress 1907-2015) [in Croatian]. Zagreb-Sarajevo: Hrvatsko Kulturno društvo Napredak; 2002. 